\title{
XII
}

\section{What Is It Like to Be Bats? Paradoxes of The Double}

\author{
Gary Saul Morson
}

\begin{abstract}
After all, what would be left of what it was like to be a bat if one removed the view point of the bat?

-Thomas Nagel, "What Is It Like to Be a Bat?"1
\end{abstract}

"The eternal silence of these infinite spaces terrifies me," wrote Pascal. ${ }^{2}$ Somehow, the "I" that is my universe is located at an infinitesimal point. How can infinity be so compact?

In War and Peace, Pierre finds this mystery comic. Captured by the French, and seated by a campfire, he bursts into laughter: "They took me and shut me up ... Who is 'me'? ... Me-is my immortal soul!" Pierre looks around at the fields, forest, "the bright shimmering horizon luring one on to infinity," and thinks, "And all that is within me, and is $m e ! . .$. And they caught all that and put it in a shed and barricaded it with planks!" ${ }^{3}$ The moment provokes Pierre's laughter because the fact it reports-consciousness located in a body-is absurd. It is unbelievable but true, which is a contradiction. And it is also both outlandish and the most common thing in the world. The fact that Pierre laughs, as if for the first time, at something we all know is what provokes the reader's

1 Thomas Nagel, Mortal Questions (Cambridge: Cambridge University Press, 1979), 173.

2 As cited in Fred R. Shapiro, ed., The Yale Book of Quotations (New Haven, CT: Yale University Press, 2006), 584.

3 Leo Tolstoy, War and Peace, trans. Ann Dunnigan (New York: Signet, 1968), 1217. 
laughter (or smile). Even to know about this fact is to experience it. "I am here"- we say it all the time - turns out to be an amazing thing to say.

How can something that has no physical presence and can contain the universe be somewhere in particular? It's like the mystery of the burning bushsomething material but defying the laws of matter-except that each of us is the one on fire. Seen tragically, it is the mystery of death. When my body dies, my consciousness dies with it. "We all die alone," as Pascal also says, and that would be true even if some nuclear Armageddon made us all die simultaneously. ${ }^{4}$ Consciousness cannot be shared. Pierre here expresses one of the ultimate mysteries. And for both Tolstoy and Dostoevsky, the important thing is to recognize that it is a mystery.

For the materialists of the Russian intelligentsia, it was not. For them, as for today's "new atheists," selfhood and consciousness do not constitute anything radically different from all those other things explained by physical science. Jacob Moleschott is supposed to have said that the brain secretes thought the way the liver secretes bile. Today some reduce thought to the firing of nerve endings, others to a sort of computer program. Daniel Dennett called his best-known work Consciousness Explained. For Dennett and Richard Dawkins, as for Chernyshevsky and Sechenov, there is no mystery.

Nagel wrote his classic essay on what it is like to be a bat to show that there is indeed a mystery. What makes consciousness mysterious is the existence of experiences that by their nature involve a point of view, a subjectivity, and so cannot be reduced to anything without a point of view:

For if the facts of experience-facts about what it is like for the experiencing organism-are accessible only from one point of view, then it is a mystery how the true character of experiences could be revealed in the physical operation of that organism. The latter is a domain of objective facts par excellence, the kind that can be observed and understood from many points of view. (emphasis in original) (Nagel, Mortal Questions, 172)

In part 1, chapter 7 of Anna Karenina, Levin overhears a debate on this question, which has remained substantially the same from that time to this.

For one group of thinkers, it is an article of faith-I use the term advisedlythat there can be no mystery, because the whole point of science, as they conceive it, is to show that the world conforms to the categories of the mind and is scientifically

4 Shapiro, Yale Book of Quotations, 584. 
knowable. Theirs is the position of Sophocles's Oedipus, who believes that human intellect can solve all riddles, but the play itself, and Greek tragedy generally, proclaims the opposite: the world defies human understanding.

Euripides ends five plays with lines affirming the ultimate unknowability of things. In Medea the chorus concludes:

Many things the gods

Achieve beyond our judgment. What we thought

Is not confirmed and what we thought not god

Contrives. $^{5}$

And at the end of Alcestis, the chorus advises:

Many are the forms of what is unknown.

Much that the gods achieve is surprise.

What we look for does not come to pass;

God finds a way for what none foresaw. ${ }^{6}$

If we step back to consider, is not the presumption that the universe must conform to the capabilities of our minds the rankest anthropomorphism? Isn't it even more anthropomorphic than the personification of natural forces, since it involves the whole universe? And does not evolution strengthen Euripides's point by prompting us to ask why the evolution of minds to suit the conditions of earth should just happen to suit everything else? Isn't that a concealed argument by design?

Dostoevsky found this presumption - that the world, including the people in it, is readily intelligible - ridiculous. And so where others saw things as easily graspable, he kept creating for the reader the sense of the mysterious. He and his characters keep telling us that human behavior does not fit existing or conceivable scientific categories. Moral questions do not reduce to physical ones. Above all, there is the mystery of consciousness.

In The Brothers Karamazov, Dmitri paraphrases Rakitin's version of Dennetry: "Imagine: inside, in the nerves, in the head-that is, these nerves are there in the brain ... (damn them!) there are these sort of tails ... and when they

5 Translation by Rex Warner in The Complete Greek Tragedies, vol. 5, Euripides I, ed. David Greene and Richmond Lattimore (New York: Modern Library, 1956), lines 1416-19.

6 Translation by Richmond Lattimore in ibid., lines 1159-62. 
quiver an image appears ... that is an object, or an action, damn it. That's why I see and then think, because of those tails, not at all because I've got a soul." "An image appears"- to whom? The explanation stops short just at the most important point, which is not how images can be created, but how they can appear as images to me, to a subjectivity. In a physical universe that in and of itself lacks point of view, each of us has one.

It should be obvious that any account of the world that does not include this point-of-viewness is leaving something out, is "incomplete," as Nagel likes to say. But science as today's materialists and those of the Russian intelligentsia understood it deals with explanations that allow for no point of view. Indeed, part of the thrill of materialist taboo-breaking comes from reducing the personal to the impersonal. Today, that is what provides the frisson to the manifestly absurd claim that authors are nothing more than the vehicle through which social forces operate. Such thrills worked its magic in Dostoevsky's time, and so he developed a series of counterthrills designed to make the opposite point. The tails of nerves don't know anything, and so they are unaware of their own existence. There is no point-of-viewness about them.

One thing we all share is that we each have something we do not share. That is why we all die alone. My consciousness is precisely mine. Typically, philosophical thought experiments about selfhood work by supposing the opposite and generating absurdity. This sort of reduction to the absurd was one of Dostoevsky's favorite kinds of humor.

Consider: If I am nothing but how I appear to the outside, why could I not be copied? If I could be, would there be two of me? (This is sometime called "the amoeba problem.") Would these two of me directly sense each other? If so, would they really be one of me in two bodies? As Siamese twins are two selves sharing part of a body, could there be Siamese selves sharing part of a me? Or would me and copy-me each be a separate me, albeit absolutely identical to its counterpart, and each sensing only its own subjectivity?

Is your double you? Our deep fascination with identical twins, still more with Siamese twins, derives from our sense that subjectivity must be unique. Golyadkin considers twinning as something resembling his experience when his precise double appears, but doubling goes a step further. Ex hypothesi, a person and his double are absolutely identical from the external standpoint.

7 Fyodor Dostoevsky, The Brothers Karamazov, trans. Constance Garnett (New York: Modern Library, 1950), 716-17. 
Identical twins do not have the same name, but the two Golyadkins do, and that is one reason our hero is especially horrified to learn that the other Golyadkin is also Yakov Petrovich! The story would not be nearly so funny if the double were, let us say, Akaky Akakievich. ${ }^{8}$

\section{"Both together is impossible"}

If there were someone exactly like me, would it be me? For a materialist, that would have to be the case, since identical causes must produce identical results. If one imagines a sort of biological 3-D printer that could make a molecularly correct exact replica of me, would there therefore be the same me in two heads? Or what? If someone exactly like me were to replace me, and no one could notice any change, would I still be there? (Does that perhaps happen when they "beam up" someone in Star Trek?)

The identity of the Golyadkins' names is, if anything, weirder than mere identity of appearance. As we would say today, it cannot be the result of DNA. It suggests an identity of persons even where we see two men, and so creates a metaphysical comedy. If the two Golyadkins are objectively absolutely the same, perhaps they are also subjectively the same, but without knowing it? Do they each have the same point-of-viewness? What would that be like?

Dostoevsky constantly plays on the identity of names suggesting an identity of identity. He milks the absurdity for all it is worth when Yakov Petrovich addresses a letter to Yakov Petrovich. Actually, and appropriately, he addresses two such letters:

\section{Dear Sir, Yakov Petrovich!}

... Your obstinate desire to persist in your course of action, sir, and forcibly to enter the circle of my existence, ... transgresses every limit imposed by the merest politeness ... I imagine there is no need, sir, for me to refer to ... your taking away my good name.... I will not allude here to your strange, one may even say, incomprehensible behavior to me in the coffee house ...

Your most humble servant,

Ya. Golyadkin

(PSS, $1: 175 ; 218-19)^{9}$

8 Of course, the story alludes to Akaky Akakievich, who is a copyist and has a double name.

9 Cited passages from The Double are from Dostoevsky's 1866 revision of the novella as it appears in F. M. Dostoevsky, Polnoe sobranie sochinenii v tridtsati tomakh [PSS], ed. V. G. Bazanov et al. (Leningrad: Nauka, 1972-1990); hereafter cited as PSS by volume and page. The 
Dear Sir, Yakov Petrovich!

Either you or I, but both together is impossible! ... However, I remain ready to oblige or to meet you with pistols.

Ya. Golyadkin

(PSS, $1: 188 ; 234)$

The endlessly varying metaphysical joke is that the two who somehow think they are different people are indeed the same person. But how can one person think he is not himself? He might somehow forget or be brainwashed about his name and even his past, but how could he be wrong about his subjectivity? To cite a famous example from John Locke, if a prince's consciousness should change places with a cobbler's, the prince would still feel his own me even if he must repair shoes. ${ }^{10}$ Others could be mistaken because they must judge from the outside, but I am me, am I not?

Locke explains: "I know that in the ordinary way of speaking, the same person, and the same man, stand for one and the same thing," but if we are really to understand "what makes the same spirit, man, or person," we must carefully distinguish these terms. ${ }^{11}$ Locke concludes that personhood is precisely consciousness. And consciousness can be in only one place at a time. If we imagine a person whose finger is cut off, and further suppose that consciousness went with the finger-so that, in a sense, it was not the finger but the rest of the body that was cut off-we would see that personhood goes with consciousness. (That is part of the joke in Gogol's "The Nose," from which Dostoevsky borrowed liberally.) Wherever consciousness may be, Locke concludes, it must still be either here or there at any given moment.

Or as Golyadkin says: "Either you or I, but both together is impossible!" Of course, he has not read any philosophy and means something like "This town isn't big enough for the two of us!" But the reader also detects the literal sense of the words: either you are me or I am me, but not both. More than one

translations are from Fyodor Dostoevsky, The Double, in The Eternal Husband and Other Stories, trans. Constance Garnett (New York: Macmillan, 1956), cited second by page number, but I have often adjusted the translation, sometimes extensively.

10 See Locke's fascinating exploration of the problem in the chapter "Of Ideas of Identity and Diversity," in John Locke, An Essay Concerning Human Understanding, ed. Alexander Campbell Fraser (New York: Dover, 1959), 1:439-70.

11 Ibid., 1:457. 
me is "impossible" - not just in the sense of "unacceptable" but also "logically incoherent." It is not taboo but senseless to say, except figuratively, that another can "enter the circle of my existence." My existence as me cannot be in two persons, and two persons cannot be one me.

And yet: the very fact that Golyadkin has to prove his point by threatening a duel suggests that he himself believes the opposite. (After all, if the two people were really one, and one Golyadkin shot the other, would he not be killing himself too? In the world of doubles, murder can be suicide, and vice versa.) Golyadkin insists, without expecting to be believed, "He's another person, your Excellency, but I'm another person too; he's apart and I am also myself by myself [sam po sebe]; I am really myself by myself," he explains, as if he needs convincing (PSS, $1: 213 ; 264$ ).

The story's deep humor derives, in short, from Golyadkin's recognition, and simultaneous refusal to recognize, that the double is not just like him but is him, and that he is his own impersonator. Jean Cocteau is supposed to have said that "Victor Hugo was a madman who thought he was Victor Hugo," but Golyadkin is a madman who worries that he isn't Golyadkin. We might sum up the point of Gogol's Dead Souls and The Inspector General as "everything is a counterfeit and there is no original," and by the same token we might paraphrase The Double as "everything is an impersonation but there is no person."

One could almost say that the master joke in all of Gogol is first to offer a fake, a copy, a forgery, a counterfeit, an impersonation, an imitation, a replica, or a representation, all of which by their very logic demand something else that is being faked or copied or impersonated or replicated, and then to deny the existence of that something else. What if (as Nozdrev suggests) there are only lies? Oh, do not trust that Nevsky Prospekt!

Dostoevsky adapts this joke, which relies on sheer nonsense, to the problem of identity. It makes no sense to deny one's own existence, but that denial expresses a fundamental human anxiety. The Underground Man needs proof that he exists, so he tries to get himself thrown out of the window, since one does not humiliate a mere object, but the officer instead moves him aside like a piece of furniture. In the same Dostoevskian spirit, Ralph Ellison's Invisible Man, remarks that not being seen, "you often doubt if you really exist." 12

12 Ralph Ellison, Invisible Man (New York: Vintage, 1972), 3. 
Horror stories (or films like Roman Polanski's The Tenant) often work by suggesting an existential threat to the hero's identity, and overtones of horror pervade The Double. If anything, Golyadkin's double is more truly him (if comparatives have any meaning here) than he is.

When Golyadkin encounters the double, we get an absurd variation on a device that goes back to Greek tragedy, Shakespeare, Gogol, and countless other dramatists-the recognition scene: "He perfectly recognized his nocturnal visitor. The nocturnal visitor was no other than himself [ne kto inoi, kak on sam ]_Mr. Golyadkin himself, another Mr. Golyadkin, but perfectly the very same as he himself [sovershenno takoi zhe, kak on sam]," a double in every respect (PSS, $1: 143 ; 179)$.

The real horror, which the hero constantly tries to ward off, is that although subjectivity is indeed unique and only one of a me can exist, the real me is not mine but his, and I am the one who does not have a $m e$ ! I am the pretender! This possibility is hard even to state precisely because we all believe that a me is directly present to itself. I might, for instance, discover that a man people took to be a certain person is his twin, and, in fact, numerous murder mysteries have turned on this possibility of misidentification from the outside. No one knows the suspect has a twin, and so he can easily create an airtight alibi while his twin commits the crime. This plot has become so familiar that it has generated a variant in which people know there are twins, and suspect the twin ruse, but both twins have airtight alibis - only they are not twins, but two of triplets.

But these "mysteries" are not at all mysterious in any fundamental way, as they would be if there were a misidentification of a subjectivity from the inside. The absurdity of such an idea suggests that we simply know, in the sense that we cannot sensibly doubt, that we have a subjectivity.

Someone might say, "Prove that it is you!," meaning that you are the person you say you are, but that would mean prove it to someone else. Proving it to yourself-proving that your me, experienced from within, is really your me-would constitute a rather different sort of challenge. In fact, proof, if one means making something that has overcome doubt, completely misses the point, because one's own existence can't be doubted to begin with. Something literally indubitable not only does not need proof, but would be compromised by it, because where there is proof there is the possibility of doubt. Usually proof is the strongest way to establish a point, but in this case it is inferior to the direct experience. 
This stronger-than-proof indubitability arises precisely because there is a pointof-view aspect of the world. We arrive again at Dostoevsky's intense sense that we cannot truly believe that a purely objective, point-of-view-less description of the world could ever be complete. The materialists must be wrong precisely because for them that description is complete.

To believe that, you might as well—Descartes notwithstanding — doubt your own existence. Strangely enough, Golyadkin does: he "even began to doubt his own existence" (PSS, $1: 147 ; 183$ ). For that matter, so does the devil in Brothers Karamazov, but there the devil himself knowingly plays the role of a metaphysical nihilist. Despite his status as a supernatural being, he is not sure whether he believes in the supernatural. What's more, he may be a merely possible being, living a merely hypothetical existence, which is why he professes to wish he could be incarnated into a fat old lady of simple faith. He even knows he is Ivan's double, perhaps just a figment of Ivan's fevered imagination, and so might very well not exist at all. Dostoevsky never tired of this joke.

\section{The Thinking Rag}

The best known passage in Pascal joins the mystery of selfhood to the nobility of thought:

Man is but a reed, the most feeble thing in nature, but he is a thinking reed. The entire universe need not arm itself to crush him.... But if the universe were to crush him, man would still be more noble than that which killed him, because he knows that he dies and the advantage the universe has over him; the universe knows nothing of this. ${ }^{13}$

The Double seems to transform these lines. Golyadkin, who is the opposite of noble, tells himself he will not "allow himself to be insulted" since he is a man, not a thing. He insists he will not "be treated like a rag... I am not a rag. I am not a rag, sir!” As if paraphrasing Golyadkin's own uncertainties from within, the narrator mocks this statement:

Possibly if someone wanted, if someone, for instance, actually insisted on turning Mr. Golyadkin into a rag, he might have done so, might have done so

13 I borrow the translation used as the epigraph for Rebecca West's novel, The Thinking Reed (New York: Viking, 1936), facing title page. 
without opposition or punishment (Mr. Golyadkin himself felt this at times) - and there would have emerged a rag and not Golyadkin-yes, a nasty, filthy rag; but this rag would not have been a simple rag, this would have been a rag with self-esteem, this rag would have had animation and feelings, even though it would have been a timid pride and timid feelings, hidden far away and deep within the folds of this rag, but all the same they would have been feelings. (PSS, 1:168; 210)

I was forced to retranslate this passage to preserve the constant repetition of the word "rag," which seems to provoke a wince of pain in Golyadkin every time it is uttered, with every wince inspiring the narrator to say it again and again.

Since only a non-thing could say it either is or is not a thing, one would think that there would be no reason to insist on one's non-thing-ness. And yet, Golyadkin does insist that he is not a thing, that he has self-esteem and feelings. For Pascal, man is a reed, but a thinking reed; for this narrator, the hero is a rag, but a feeling rag. Not just thinking, but feeling-because, for Dostoevsky, it is not consciousness, or even self-consciousness, but the particular sort of agonizing self-consciousness we call humiliation that makes us human.

We have moved from man as un roseau pensant ("a thinking reed") to man as un chiffon tremblant ("a trembling rag"). Pascal's thinking reed is overwhelmed only by the universe's physical force, but Dostoevsky's rag is also overwhelmed by society's moral force. Physical force at least leaves the self with nobility, but social force strips away that, too. When Dmitri Karamazov must strip, he feels his very self exposed. All stripping, physical or moral, is unspeakably painfulDostoevsky's Underground Man compares it to being flayed alive-and it seems to explain the etymology of the hero's name, Golyadkin (from golyi, "naked"). The narrator seems to revel in inflicting such pain.

Descartes pointed to thought, but other philosophers have argued that pain proves consciousness still more clearly. When in pain, even a materialist who regards thought as analogous to bile cannot doubt, can barely pretend to doubt, that he is in pain. That is why the Underground Man speaks of an educated man of the nineteenth century who is suffering from toothache. Just try to be a materialist with aching teeth! As there are no atheists in foxholes, so there are no materialists in dental chairs. 
But Dostoevsky knows that pain is not enough to make us human. Animals, after all, also suffer pain. What they are missing is humiliation. Pain proves we have a subjectivity, but humiliation proves we have a social subjectivity, and human subjectivity is essentially social. I am humiliated, therefore I am human. It has been said that all of Dostoevsky's novels could be called Crime and Punishment, and we may add that they could also be called The Insulted and the Humiliated.

Golyadkin's inner discourse constantly reflects his awareness of being spied on, judged, regarded as strange. And so he constantly assures himself that he is all right, just like everyone else, and why should he not be? When he leaves the doctor's office, he looks up and sees the doctor watching him from the window. It is a sort of early study in Stavrogin's resentment of Tikhon as a spy into his soul.

The "feeling rag" passage captures this sense of humiliation at its most vertiginous. Constantly, as Bakhtin notes, Golyadkin simulates "independence and indifference ... directed not outward, not toward another, but toward Golyadkin's own self: he persuades himself, reassures and comforts himself, plays the role of another person vis-à-vis himself. Golyadkin's comforting dialogues with himself are the most prominent trait of the whole story." ${ }^{14}$ And these dialogues are themselves the result of "the total nonrecognition of his personality on the part of others," including the narrator-and even, we may add, of himself. ${ }^{15}$ Because of the narrator's taunting tone, readers simultaneously occupy the role of humiliator and humiliated, as they both identify with Golyadkin and laugh at him.

\section{The Bad Samaritan}

At the beginning of the "Rebellion" chapter, Ivan Karamazov maintains that one cannot truly love one's neighbor, simply because he is he and I am I and that difference is unbridgeable. There can be no real empathy, any more than my me can be experienced as if it were someone else's me. Ivan breaks out of this circle of self when he returns to help the drunken peasant freezing in the snow. The incident alludes to Jesus's story of the man who had "fallen among thieves" and been left naked and half-dead. A priest sees him and passes by "on the other

14 Mikhail Bakhtin, Problems of Dostoevsky's Poetics, trans. Caryl Emerson (Minneapolis: University of Minnesota Press, 1984), 212.

15 Ibid., 215. 
side," as does a Levite. But a good Samaritan "had compassion on him" (Luke 10:33). Jesus tells the story to explain what it means to "love thy neighbor," which, after caring for the peasant, Ivan now recognizes is indeed possible. For Ivan, the discovery comes too late, but for Golyadkin it does not come at all. That is why we sense there is hope for Ivan's, but not Golyadkin's, recovery from insanity.

I think the key incident in The Double has been overlooked. Let us call it "the bad Samaritan." When the double follows Golyadkin home, Golyadkin takes him in and, apparently, pities him. The new Golyadkin is a picture of humiliation as only Dostoevsky can describe it:

There was a downtrodden, crushed, scared look about all his gestures, so that-if the comparison might be allowed-he was at that moment rather like the man who, having lost his clothes, is dressed up in someone else's: the sleeves work up to the elbows, the waist is almost up to his neck, and he keeps every minute pulling down the short waistcoat; he wriggles sideways and turns away, tries to hide himself, or peeps into every face, and listens whether people are talking of his position, laughing at him or putting him to shame-and he is crimson with shame and overwhelmed with confusion and wounded vanity. (PSS, $1: 153 ; 191$ )

He is more naked clothed than nude. This poor soul is fallen among Petersburgers, stripped not physically but morally. For a moment, Golyadkin is "genuinely touched" (PSS, 1:156; 194). But almost immediately his mood takes on-if the phrase may be allowed - a Dostoevskian quality: "In short, Mr. Golyadkin was quite happy ... because, so far from being afraid of his enemies, he was quite prepared now to challenge them all to mortal combat ... [and] because he was now in the role of a patron" (PSS, 1:157; 195).

Golyadkin has the chance to show compassion and care for the other person for the sake of the other person. But he treats the other as-well, as an extension of himself. He sees in his pitiful companion someone who will toady up to him as Golyadkin has toadied up to others; and, still worse, he values him as someone who will be his ally in intrigues against those others.

For Golyadkin, others exist either to intrigue against him or to be intrigued against, much as the Underground Man can only imagine love as dominating or being dominated. The only empathy Golyadkin knows comes from recognizing another person as an inflictor of pain or an object of patronage. When the 
double starts to torment Golyadkin, he is only enacting Golyadkin's own intentions. It is, of course, because the double knows Golyadkin so intimately that he can touch his sore spots with such uncanny accuracy.

Empathy is necessary for morality, but not sufficient, as every good con man knows. The reason that, as Dostoevsky repeatedly suggests, former victims make the most skilled torturers is that they know just what hurts the most. For the same reason empathy can be used not to comfort but to exacerbate. The double makes full, sadistic use of this privilege. For who knows better how to torment oneself than one's own replica, and who loves being in the dominating position more than Golyadkin himself? This is one case where the punishment fits the crime precisely. In this sense, The Double is an early version of Crime and Punishment. Golyadkin gets exactly what he deserves, and his suffering (and ours along with him) is all the more acute because of it.

From this point on, the story logically unfolds with a mounting humiliation leading to the madhouse. The story ends: "Our hero shrieked and clutched his head in his hands. Alas! For a long while he had been haunted by a presentiment of this!" (PSS, 1:229; 284). A presentiment, or fore-feeling, is a sort of temporal double. The sense of inevitability derives from the fact that the forefelt event is a repetition of what was already long there. And yet: for one moment, the moment when he felt genuine sympathy, he could have escaped the logic of doubling, leaving his own shadow behind.

One can see each of Dostoevsky's works as intensifying one or another sense of the mysterious. When Svidrigailov and Stavrogin come to disbelieve absolutely in the mysterious, and see the world as completely banal, they kill themselves, but they are not the characters furthest from Dostoevsky's own viewpoint. At least they look for mystery. That is why Svidrigailov sees, and is glad he sees, ghosts, even if they are themselves banal spirits. Fyodor Pavlovich at least feels mystical terror. No, the characters most distant from the author are those who do not even look for mystery and who are smugly sure that only the stupid, the superstitious, and the religious believe in it. The real villains of Brothers Karamazov are Smerdyakov and his petty double, Rakitin. 
It is sometimes said that with the passing of communism, Dostoevsky's relevance has faded a bit, but I think that the prevalence of both sociological and neurologic challenges to the ultimate mysteries makes him more pertinent than ever. The intellectual West has grown hostile to religion because, as Dostoevsky foresaw, it has come to disbelieve not just in God but in the very subject who could experience belief. Killing subjectivity has proven harder than killing God because subjectivity is directly experienced. But it can still be treated as a mirage, a double of something that does not exist. ${ }^{16}$

16 I have developed these ideas on The Double in a longer essay, "Me and My Double: Selfhood, Consciousness, and Empathy in The Double," in Before They Were Titans: Essays on the Early Works of Dostoevsky and Tolstoy, ed. Elizabeth Cheresh Allen (Boston: Academic Studies Press, 2015), 43-60. 